\title{
LETTER
}

\section{Non-invasive ventilation in acute respiratory failure related to 2009 pandemic Influenza A/H1N1 virus infection}

\author{
João Carlos Winck ${ }^{* 1,2}$ and Anabela Marinho' \\ See related research by Rello et al., http://ccforum.com/content/13/5/R148
}

\begin{abstract}
Non-invasive ventilation (NIV) is considered first-line intervention for different causes of acute respiratory failure [1]. However, Rello and colleagues [2] show high rates of NIV failure in pandemic Influenza A/H1N1 virus infection (PH1N1).

We describe a patient with PH1N1 in whom NIV was effective. A 53-year-old male was admitted in November 2009 with cough, dyspnea, and hemoptysis. His temperature was $38.9^{\circ} \mathrm{C}$, he was tachypneic, with diffuse rhonchi and bilateral crackles, and oxygen saturation was $96 \%$ (4 $\mathrm{L} / \mathrm{min}$ oxygen). Arterial partial pressure of oxygen $\left(\mathrm{PaO}_{2}\right)$ and arterial partial pressure of carbon dioxide $\left(\mathrm{PaCO}_{2}\right)$ were 76 and $23 \mathrm{~mm} \mathrm{Hg}$, respectively. Creatine kinase $(2,278 \mathrm{U} / \mathrm{L})$ and brain natriuretic peptide $(3,544 \mathrm{pg} /$ $\mathrm{mL}$ ) were increased. Acute myocardial infarction was excluded. Chest $\mathrm{x}$-ray showed bilateral interstitial infiltrates and cardiomegaly. Echocardiogram showed severe left ventricular systolic dysfunction. PH1N1 pneumonia was suspected, and oseltamivir was administered in
\end{abstract}

association with antibiotics and diuretics. On day 2, a nasopharyngeal swab was positive for PH1N1. The patient was subsequently transferred to a negativepressure ward. He was still tachypneic, with basal crackles and a $\mathrm{PaO}_{2} /$ fraction of inspired oxygen $\left(\mathrm{FiO}_{2}\right)$ ratio of 246. NIV (BiPAP Vision; Philips Respironics, Murrysville, PA, USA) through an oro-nasal mask in bilevel positive airway pressure mode (inspiratory positive airway pressure [IPAP] $=16 \mathrm{~cm} \mathrm{H}_{2} \mathrm{O}$, expiratory positive airway pressure [EPAP] $=8 \mathrm{~cm} \mathrm{H}_{2} \mathrm{O}$ ) was started. Due to patient preference, the mode was changed to continuous positive airway pressure (CPAP) at $10 \mathrm{~cm} \mathrm{H}_{2} \mathrm{O}$ and an $\mathrm{FiO}_{2}$ of $25 \%$. After 1 hour, $\mathrm{PaO}_{2} / \mathrm{FiO}_{2}$ increased to 364, and CPAP was stopped after 12 hours.

Recently, Djibré and colleagues [3] demonstrated the effectiveness of NIV in acute respiratory distress syndrome related to PH1N1 pneumonia. Our case further supports its role in a hypoxemic patient with cardiogenic pulmonary edema and PH1N1 pneumonitis.

\section{Authors' response}

Alejandro Rodríguez, Thiago Lisboa, Jordi Rello and H1N1 SEMICYUC Working Group

We appreciate the interest from Winck and Marinho in our article and their insightful observations regarding non-invasive ventilation (NIV) in severe influenza A (H1N1)v. The use of NIV in hypoxemic respiratory failure is controversial, and the etiology of hypoxemia appears to be an important determinant of its success. A metaanalysis [4] suggests that non-invasive positive-pressure ventilation does not decrease the need for intubation, so

\footnotetext{
*Correspondence: jwinck@hsjoao min-saude pt
}

'Pneumology Department, Faculdade de Medicina da Universidade do Porto, São João Hospital, Alameda Professor Hernâni Monteiro; 4303-451 Porto, Portugal Full list of author information is available at the end of the article there is not enough evidence to support its use in acute respiratory distress syndrome. Our experience [2] is consistent with other reports [5,6]; $25 \%$ to $30 \%$ of patients were non-invasively ventilated on admission, but $70 \%$ to $85 \%$ of these patients required subsequent intubation and invasive ventilation. There are only a few patients with H1N1-related respiratory failure who seem to benefit from NIV alone, so it should be reserved for patients with milder disease. Guidelines endorsed by the European Respiratory Society and European Society of Intensive Care Medicine [7] conclude that, as a general rule, NIV not be recommended as an alternative to invasive ventilation in patients affected by H1N1. In spite of this, selected patients with hypoxemia and additional cardiac compromise (severe left ventricular systolic dysfunction) 
or presenting with exacerbation of chronic obstructive pulmonary disease might benefit from this alternative therapy as it has been reported.

\section{Abbreviations}

CPAP, continuous positive airway pressure; $\mathrm{FiO}_{2}$, fraction of inspired oxygen: $\mathrm{NIV}$, non-invasive ventilation; $\mathrm{PaO}_{2}$, arterial partial pressure of oxygen; $\mathrm{PH} 1 \mathrm{~N} 1$, pandemic Influenza A/H1N1 virus infection.

\section{Competing interests}

The authors declare that they have no competing interests.

\section{Acknowledgments}

Written consent for publication was obtained from the patient.

\section{Author details}

'Pneumology Department, Faculdade de Medicina da Universidade do Porto, São João Hospital, Alameda Professor Hernâni Monteiro; 4303-451 Porto,

Portugal. 'Faculdade de Medicina da Universidade do Porto, São João Hospital, Alameda Professor Hernâni Monteiro; 4303-451 Porto, Portugal

\section{Published: 19 March 2010}

\section{References}

1. Brochard $L$ : Noninvasive ventilation for acute respiratory failure. JAMA 2002, 288:932-935.
2. Rello J, Rodríguez A, Ibañez P, Socias L, Cebrian J, Marques A, Guerrero J, Ruiz-Santana S, Marquez E, Del Nogal-Saez F, Alvarez-Lerma F, Martínez S, Ferrer M, Avellanas M, Granada R, Maraví-Poma E, Albert P, Sierra R, Vidaur L, Ortiz P, Prieto del Portillo I, Galván B, León-Gil C; H1N1 SEMICYUC Working Group: Intensive care adult patients with severe respiratory failure caused by Influenza A (H1N1)v in Spain. Crit Care 2009, 13:R148.

3. Djibré M, Berkane N, Salengro A, Ferrand E, Denis M, Chalumeau-Lemoine L, Parrot A, Mayaud C, Fartoukh M: Non-invasive management of acute respiratory distress syndrome related to Influenza $A(H 1 N 1)$ virus pneumonia in a pregnant woman. Intensive Care Med 2010, 36:373-374.

4. Agarwal R, Reddy C, Aggarrwal AN, Gupta D: Is there a role for noninvasive ventilation in acute respiratory distress syndrome? A meta-analysis. Respir Med 2006, 100:2235-2238

5. Ramsey CD, Funk D, Miller III DF, Kumar A: Ventilator management for hypoxemic respiratory failure attributable to $\mathrm{H} 1 \mathrm{~N} 1$ novel swine origin influenza virus. Crit Care Med 2010, 3 (suppl).

6. Rodriguez A, Lisboa T, Rello J: Pandemic influenza A (H1N1)v in the intensive care unit: what have we learned? Arch Bronchoneumol 2010, 46(suppl 2):24-31.

7. Conti G, Larrsson A, Nava S, Navalesi P: On the role of non-invasive (NIV) to treat patients during the H1N1 influenza pandemic [http://dev.ersnet.org/ uploads/Document/63/WEB_CHEMIN_5410_1258624143.pdf]

doi:10.1186/cc8896

Cite this article as: Winck JC, Marinho A: Non-invasive ventilation in acute respiratory failure related to 2009 pandemic Influenza A/H1N1 virus infection. Critical Care 2010, 14:408. 